\title{
Development Of Higher Education In Albania
}

\author{
Sonila Xhafa, Ph.D., University of Tirana, Albania
}

\begin{abstract}
Albania is looking to take its place within Europe. To do so, the nation needs to develop more skilled and educated working population. Following the political and economic changes of 1991, the system of higher education in Albania has not necessarily been adequately organised or capable of providing a sufficiently high-quality education. This paper will present some information on higher education (including degree and diploma programmes) in Albania during the transition and in the present day, and give attention to the development of higher education in the country and conclude with some suggestions for improving public universities and education infrastructure and increasing the quality of the experience undergone by both students and academic staff.
\end{abstract}

Keywords: Albania; Higher education; Educational Development; Education Infrastructure

\section{INTRODUCTION}

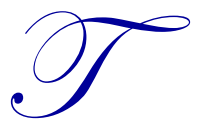

he development of higher education in Albania began in 1946 with the construction of a two-year pedagogical institute in Tirana that was only involved in teaching pedagogy During the first year, enrollment was 53 students with 24 of them continuing their studies in the full-time system and 29 others continuing in the part time system. ${ }^{1}$ In 1957 the country's first university institution, State University of Tirana, was founded. Until 1991 it was a typical Eastern European institution of higher education. It was founded through the merging of six existing institutions. In 1991 the University of Tirana separated the engineering faculties, creating Polytechnic University of Tirana. Currently, the University of Tirana includes 8 faculties (Faculty of Economy, Faculty of History and Philology, Faculty of Justice, Faculty of Social Sciences, Faculty of Natural Sciences, Faculty of Foreign Languages, Faculty of Medicine and Faculty of Nursing) and 50 academic departments.

\section{STRUCTURE AND ORGANIZATION OF HIGHER EDUCATION IN ALBANIA}

The system of higher education in Albania is structured into three types of institution: universities, academies, and non-university schools. The country has 13 public universities that offer university-level Bachelor degrees. The most recently opened are Aleksander Moisiu University of Durres, which was opened in September 2006, and the University of Sports in Tirana (formerly the Academy of Physical Training and Sports). Higher education institutions in Albania also offer two-year non-university diploma programmes in various professional fields. These studies contain at least $120 \mathrm{ECTS}^{2}$ and last at least 2 years. These credits can be transferred into other first-cycle university programmes.

\footnotetext{
${ }^{1}$ Vjetari Statistikor i Shqiperise, Tirane, 1963

2 European Credit Transfer and Accumulation System, is a standard for comparing the study attainment and performance of students of higher education across the European Union and other collaborating European countries.
} 


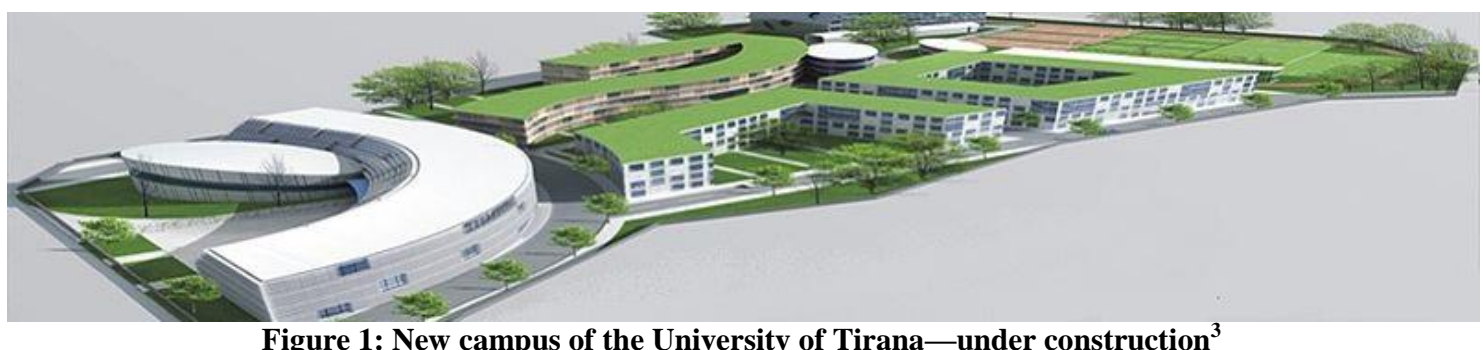

Figure 1: New campus of the University of Tirana-under construction ${ }^{3}$

The types of programmes offered in the Albanian system as set out by the Law No. 10-307, passed 22 July 2010, are as follows:

- $\quad$ Bachelor's programmes, corresponding to the first cycle of studies, (Bachelor degree, 180 ECTS).

- Master's programmes, corresponding to the second cycle of studies (e.g. Master of Science degree, two years, 120 ECTS)

- $\quad$ Professional Master programmes (Master Professional degree, 1.5 years, 60-90 ECTS)

- Integrated study programmes part of the second cycle (i.e. Master's-level programs, Master of Science, 2 years, 300 ECTS)

- $\quad$ Doctoral programmes or the 'third cycle'. PhD studies are based on scientific research and independent activity and amount to 60 ECTS, with a duration of at least three academic years.

- $\quad$ Long-term specializations are part of the second cycle. They are professional qualification programs that offer advanced studies in fields such as medicine, dentistry, pharmacy, engineering, law, veterinary studies, etc.

The academic year consists of two semesters. Each semester usually lasts for 15 weeks. The first semester starts in October, the second semester in March. Exams (sat by students in the first and second cycles of studies) are organized at the end of each semester and include oral and written exams. The curriculum of each academic year is organized by modules. Educational programmes and the approval of new courses are standardised according to the requirements of the national Ministry of Education and Science.

All programmes are certified by the state, based on governing guidelines and laws. Curriculum is formulated by the department. A university is managed by a Rector and a University Senate, consisting of representatives of various stakeholders from each faculty.

Since 1998, a system of distance education has existed, managed by the National Centre of Distance Education and distance education departments established at the Polytechnic University of Tirana, Tirana University, and Shkoder University.

Higher education institutions are accredited by the Public Higher Education Accreditation Agency, founded in 1999 as a part of the Ministry of Education and Science. This agency defines the criteria for accreditation of institutions of higher education. The purpose of this accreditation system is to use standards of evaluation to ensure quality education, encourage institutions to improve education quality, ensure the accountability of educational institutions, and foster public confidence in educational institutions.

Public higher education in Albania is currently characterized by dynamic development, as seen in:

- Yearly increase in the number of students. Since 1994, the number of enrolled and graduated students has nearly doubled, at almost $4.7 \%$ annually. ${ }^{4}$ Demand for higher education is growing around the country. According to the Ministry of Education and Science, about 53\% of high school graduates are registered to

${ }_{4}^{3}$ http://www.unitir.edu.al/

${ }_{4}$ Calculated by author. 
attend full-time studies at public universities. ${ }^{5}$

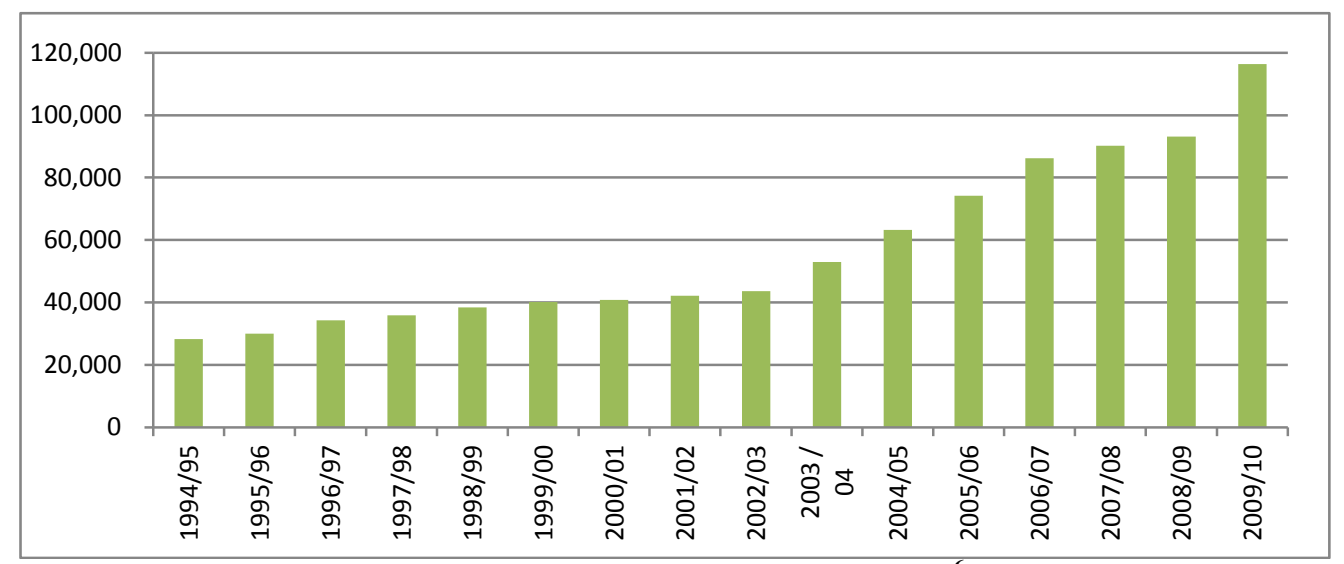

Figure 2: Number of students across years ${ }^{6}$

- $\quad$ The rapid development of new curricula adapted to Western standards.

- $\quad$ An increasing number of private institutions of higher education. One new development in the second decade of transition has been the emergence and consolidation of private education. In October 2002, the first private university, 'University of New York Tirana' with a focus in economic sciences, was opened, and since then the number of private institutions of higher education in Albania has increased every year. Currently there are over 30 accredited private universities focusing on fields including medicine, law and social sciences, economics etc.

In addition, in order to meet the challenges of transition, since 1992 there have been collaborations of a scientific character between Albanian and foreign universities, involving exchange of knowledge and experiences between staff and students. Nowadays, Albanian higher education institutions provide scientific research, development projects, and other innovative activities. Public universities receive a separate budget for research activities from the Ministry of Education and Science, separate from their education funding. They aim to assure the integration of the teaching and research processes. For instance, for a long period, several Italian universities have been working on a number of small- and large-scale projects with Albanian universities.

Another positive development is cooperation since 1992 with universities in Greece (Ioannina University, Athena University, Aegean University), Russia (Lomonosov Moscow State University), Germany (University of Siegen, University of Bamberg), Switzerland (University of Geneva), Bulgaria (Sofia University 'ST. Kliment Ohridski'), Macedonia (State University of Tetovo) and Turkey (Instambul University) etc.

Table 1: Number of projects in which one or several Albanian institutions have been involved

\begin{tabular}{|l|c|c|c|c|c|}
\hline & Tempus I And II & Tempus III & \multicolumn{3}{|c|}{ Tempus IV } \\
\cline { 2 - 6 } & $\mathbf{1 9 9 0 - 1 9 9 9}$ & $\mathbf{2 0 0 0 - 2 0 0 6}$ & $\mathbf{2 0 0 8}$ & $\mathbf{2 0 0 9}$ & $\mathbf{2 0 1 0}$ \\
\hline Joint European Project & 50 & 40 & 7 & 3 & 4 \\
\hline
\end{tabular}

Source: Albanian Ministry of Education and Science

Albania has also participated in Tempus projects since 1992, in accordance with the nation's general education strategy. The priorities have been study programmes, training of teachers, and administrators, and restructuring of the physical infrastructure.

\footnotetext{
${ }^{5}$ Declared by Albanian Ministry of Education and Science

${ }^{6}$ Ministry of Education and Science, 'Annual Statistical Report of Education, 2009-2010.'
}

(C) 2013 The Clute Institute http://www.cluteinstitute.com/ 
Table 2: Number of students and academic staff participating in the TEMPUS programme

\begin{tabular}{|l|c|c|c|c|c|c|c|}
\hline & $\mathbf{2 0 0 4 - 2 0 0 5}$ & $\mathbf{2 0 0 5}-\mathbf{2 0 0 6}$ & $\mathbf{2 0 0 6}-\mathbf{2 0 0 7}$ & $\mathbf{2 0 0 7 - 2 0 0 8}$ & $\mathbf{2 0 0 8}-\mathbf{2 0 0 9}$ & $\mathbf{2 0 0 9}-\mathbf{2 0 1 0}$ & $\mathbf{2 0 1 0 - 2 0 1 1}$ \\
\hline Students & 2 & 4 & 4 & 26 & 19 & 19 & 17 \\
\hline Academic staff & - & 1 & - & 2 & - & - & - \\
\hline
\end{tabular}

Source: Ministry of Education and Science

\section{Gaps And Problems In The Development Of Higher Education In Albania}

Higher education and scientific research in Albania are not yet fully developed. Some deficiencies and problems that affect quality are:

- $\quad$ High student/academic staff ratio. Increasing numbers of students should be provided for by teacher hires to provide adequate service. In 2010, the ratio was about $26^{7}$ compared to the European standard 20, showing the need for an increase.

- $\quad$ The large gap that exists between part-time and full-time students in teaching quality and even in the labour market. ${ }^{8}$ In recent years, the number of full-time and part time students has increased a lot. This situation has negatively affected the quality of teaching for both types of students.

- Very limited research activity among academic staff. Research activity in universities today is focused mostly in applied sciences and technical fields.

- $\quad$ Low levels of implementation of contemporary methods of teaching which thus do not meet present and future needs. Investment to improve teaching, in particular regarding the implementation of modern methods, has been insufficient.

- Insufficient numbers of qualified academic staff with higher degrees.

- Insufficient technical infrastructure. Teaching and research need to be covered with a minimum of laboratory and other equipment. This lack limits faculty and student research activity.

- Deficits in the funding system, which is highly centralized, static, and not oriented towards the real needs of higher education. Often, the planned annual budget and additional investments are insufficient and do not meet basic needs; in general, not enough of the education budget is allocated to higher education. The debate on autonomy in higher education is linked to the problem of funding higher education and the choice of financial management systems. This pending issue has started since 2005, when the universities asked for financial autonomy, in order to decide themselves for the use of the generated university incomes.

- $\quad$ Poor efforts to ensure compatibility with foreign university degrees, especially in the context of the implementation of the Bologna Charter ensuring convertibility among degrees in European nations. On 18 September 2003, Albania officially joined the Bologna process. Since then, higher education legislation in the country has been updated with a view to supporting Bologna reforms and responding to national needs. The reform process has addressed issues such as study cycles, the introduction of ECTS, funding of higher education, academic standards, teaching loads, and student admissions. This last issue is related to the necessity of the implementation of more rigorous criteria and procedures.

\section{CONCLUSIONS}

One of the challenges of socio-economic development in general is to increase the quality of higher education. This can be done by several means:

- Increasing the quality of teaching. Opportunities are needed for increased collaboration with universities, institutes, and research centres abroad, in order to integrate national research activities with scientific and technological developments in the region, Europe, and the world. It is important that faculty undertake scholarship to keep them up to date with new developments in the fields in which they teach.

- Increasing the effectiveness and efficiency of academic and administrative staff in all institutions of high education.

- Implementing better technology in teaching and managing the entire education system.

\footnotetext{
${ }^{7}$ Ministry of Education and Science, Directory of Higher Education (2010).

${ }^{8}$ Ministry of Education and Science, Directory of Higher Education (2010.
} 
- Improving the physical infrastructure, technical methods, and pedagogy in order to optimize learning conditions.

- $\quad$ Compiling programmes fostering increased research potential in the country and an orientation to the local district and region.

- Improving and reforming existing curricula at all levels and developing new curricula in conformity to the needs of the labour market, future socio-economic development, and European standards.

- $\quad$ Expanding the role of universities in their districts. As in many other countries, there is a benefit to defining a clearer role for regional universities in the economic and social development of their regions and local areas. This will require universities to be much more active within their local communities and economies, finding ways to help their economies to grow and thrive.

- $\quad$ Review of the standards of acceptance and enrolment of part-time students as compared to those of fulltime students.

- Increasing the financial autonomy of higher education institutions.

\section{AUTHOR INFORMATION}

Sonila Xhafa was born in Durrës, Albania, on 23 May 1982. In July 2004, she graduated from the University of Tirana, where she earned Bachelor degree in Geography. In September 2011, she received her PhD in Demographic and Urban Development and Territorial Planning. Since 2005, she has worked as an Assistant Professor in the Department of Geography of the University of Tirana and recently as a lector with the academic degree of Docent. ${ }^{9}$ She is the author of many scientific papers presented at different national and international conferences. Sonila Xhafa, Ph.D., Faculty of History and Philology, University of Tirana, Albania. E-mail: sonilaxhafa@gmail.com

\section{REFERENCES}

1. Albanian Ministry of Education and Science. (2005). National Education Strategy, 2004-2015. Tirana: Government of Albania.

2. Albanian Ministry of Education and Science, (2009) Annual statistical reports education, 2009-2010. Tirana: Government of Albania

3. Kambo, E. (2005). Arsimi ne Shqiperi (1945-1960)

4. Samson, I. (1996). Albanian experience among transition trajectories. Working Paper, Université PierreMendès - France, Grenoble.

5. United Nations Development Programme. (1998). Albanian Human Development report. Tirana: UNDP.

6. United Nations Development Programme. (2007). Albania Millennium Development Goals. Tirana: UNDP.

7. Dudwick, N., \& H. Shahriari. (2000). Education in Albania-attitudes and expectations. Tirana: The World Bank.

\footnotetext{
${ }^{9}$ Docent is a title at some European universities to denote a specific academic nomination within a set structure of academic ranks below professor
}

(C) 2013 The Clute Institute http://www.cluteinstitute.com/ 


\section{NOTES}

